https://helda.helsinki.fi

Constitutionalism as mindset : reflections on Kantian themes about international law and globalization

Koskenniemi, Martti

2007

Koskenniemi , M 2007 , ' Constitutionalism as mindset : reflections on Kantian themes about international law and globalization ', Theoretical inquiries in law , vol. 8 , no. 1 , pp. 9-36 .

http://hdl.handle.net/10138/231001

publishedVersion

Downloaded from Helda, University of Helsinki institutional repository.

This is an electronic reprint of the original article.

This reprint may differ from the original in pagination and typographic detail.

Please cite the original version. 


\title{
Constitutionalism as Mindset: Reflections on Kantian Themes About International Law and Globalization
}

\begin{abstract}
Martti Koskenniemi*
Globalization is a topic of some anxiety among international lawyers. On the one hand, its fluid dynamics - fragmentation, deformalization and empire - undermine traditional diplomatic rules and institutions. On the other hand, the effort to reimagine international law in purely managerial terms appears intellectually shallow and politically objectionable. To avoid marginalization and instrumentalization, many lawyers have begun to think about international problems through a constitutional vocabulary and have often cited Kant in that connection. This Article argues that, while it is always possible to grasp the world through a constitutional vocabulary, this does not provide determinate answers to international problems. Instead of an institutional architecture or a set of legal rules, constitutionalism is best seen as a mindset - a tradition and a sensibility about how to act in a political world. Contrary to a widespread assumption, Kant's political writings may also be read in this fashion and, if so, a meaningful international transformation might necessitate not only legislative or institutional intervention but a professional and perhaps spiritual regeneration.
\end{abstract}

I.

In the Critique of Pure Reason (1781), Kant notes that rules do not spell out the conditions of their own application. Every rule needs, for its application,

* Professor of International Law at the University of Helsinki and Global Professor of Law at New York University. 
an auctoritatis interpositio that determines what the rule should mean in a particular case and whether, all things considered, applying the rule might be better than resorting to the exception. In Kant's vivid language:

A physician therefore, a judge or a statesman, may have in his head many admirable pathological, juridical or political rules, in a degree that may enable him to be a profound teacher in his particular science, and yet in the application of these rules he may very possibly blunder - either because he is wanting in natural judgment (though not in understanding), and whilst he can comprehend the general in abstracto, cannot distinguish whether a particular case in concreto ought to rank under the former; or because his faculty of judgment has not been sufficiently exercised by examples and real practice. ${ }^{1}$

In view of this, what is the meaning of the rule of law? And especially of the rule of law beyond the legal system of the state? For Kant, the transition from the state of nature to a condition of lawfulness (right) was a moral obligation because it summed up the "conditions under which the choice of one can be united with the choice of another in accordance with a universal law of freedom."2 Yet, even in what Kant termed "republics," freedom remained precarious as long as the threat of international war loomed in the background. Nations, therefore, had an analogous obligation to relinquish the "lawless freedom" of the state of nature that marked the relationship between them, renounce war, and join in a federation of free republics that might set a world federation as their objective. ${ }^{3}$ Although Kant's formulation of the federal objective in his different writings varied, he consistently pointed out that only an international condition of (public) right (or of lawfulness) was morally acceptable, because this was the only option able to bring about the condition

1 Immanuel Kant, CRITIQue OF PuRe ReAson 140-41 (Vasilis Politis ed., Everyman's 1991) (1781) (A132-34). The exercise of judgment, Kant notes, requires "mother wit," for which there are no rules and "the want of which no schooling can compensate." Although Kant says here in a footnote, id. at 140 n.1, "[d]eficiency in judgment is properly that which is called stupidity," in his later writings, and especially in the Third Critique, his assessment is less harsh.

2 ImMAnuel Kant, The MetaPhysics OF MoRAls 230 (Mary Gregor ed., Cambridge Univ. Press 1996) (1797) (6:230).

3 IMMANUEL KANT, Idea for a Universal History with a Cosmopolitan Purpose, in POLITICAL Writings 41, 50-51 (Hans Reiss ed., 2d ed. 1991) [hereinafter KANT, Universal History]; IMmanuel KANT, Perpetual Peace: A Philosophical Sketch, in Political Writings, supra, at 93, 102-05 [hereinafter Kant, Perpetual Peace]; KANT, supra note 2, at 119-22 (6:350-53). 
of freedom that, as he once noted, was "the inner value of the world"4 and the final end of creation. ${ }^{5}$

If the rules of law do not spell out the conditions of their application, however, then their moral virtue (or their political point) cannot rest on the formulations of positive laws or on what they purport to achieve in practice, and any moral, i.e. freedom-enhancing quality, will simply depend on their character as legal rules, on the legal proprium. The merit of law would then not be that it contains, as it were, the contours of the ideal social relationships suitable for each context and period. These will always be left to the normative imagination of the auctoritatis interpositio, whose judgment in the application of the law becomes the visible, public law face of freedom.

The project of fidelity to the "rule of law," then, cannot be reduced to fidelity to the purported meaning of particular laws or to the objectives projected on them. What laws mean and the objectives they may appear to have will depend on the judgment of the law-applier. And that judgment, the act of competent creation of an individual norm is, as Kelsen would say, a political act. After all, "there is no criterion on the basis of which one of the possibilities given within the frame of the norm to be applied could be favoured over the other possibilities." ${ }^{6}$ If for Kant (and for Kelsen) the transition from the realm of nature (or from raw desire and violence) to the realm of freedom in a "kingdom of ends" takes place through law, this transition depends less on the inner force of (external) legislation than on the moral rectitude of those whose task is to apply it. As is well known, Kant's view of law is embedded in his philosophy of history. Progress toward increasing freedom becomes possible only if the experiences of the complex, obstacle-laden learning process that is history are integrated into the practice of judgment. In this perception, jurists rather than positive rules become law's nucleus, as educators and enlighteners, a conclusion that Savigny, soon after Kant, drew from the historicity of law. ${ }^{7}$

What is the implication of this perception for the moral (political) ideal of

4 Immanuel Kant, Lectures (1780), cited in PAUl GuYER, KANT ON FrEedOM, LAW AND HAPPINESS 129 (2000).

5 Immanuel Kant, CRitique of the Power of Judgment $\S 84$, at 302-03 (Paul Guyer ed., Cambridge Univ. Press 2000) (1790) (5:435-36).

6 Hans Kelsen, Introduction to Problems of Legal Theory 81 (Bonnie L. Paulson \& Stanley L. Paulson trans., Clarendon 1992) (1934).

7 This image of jurists is very different from Kant's, who held that jurists should know the codes rather than discuss their justification, a task Kant reserved for philosophers. See ImMANuel Kant, Der Strait der Fakultäten, in ReCHTSLEHRE. SCHRIFTEN ZUR RECHTSPHILOSOPHIE 371 (1988) (24-25); and see comments, e.g., 
the rule of law? First, it suggests that the rule of law cannot mean "legalism" in the form of fidelity to any particular meaning of the law as text or practice. Second, it cannot mean "instrumentalism" either, defined as the systemic effort to look beyond legal rules to their assumed objectives. Instead, I will argue that the rule of law in this Kantian image relates to the way the lawapplier (administrator, public official, lawyer) approaches the task of judging within the narrow space between fixed textual understandings (positivism) on the one hand, and predetermined functional objectives (naturalism) on the other, without endorsing the proposition that the decisions emerge from a "legal nothing" (decisionism). I think about this in terms of the spirit, or better, the mindset, of the legal profession.

\section{II.}

International law has never been a sociologically thick aspect of the international world. Since its inception, however, international law has been embedded in the optimistic trajectory sketched by Kant in his 1784 essay on The Idea for Universal History with a Cosmopolitan Purpose. ${ }^{8}$ Whatever doubts one may harbour against the natural teleology animating this essay (and the Critique of the Power of Judgment of $1790^{9}$ ), this idea continues to inform much of the political project behind international law. ${ }^{10}$

After the end of the Cold War, this project seemed to gain new force. New aspects of international relations began to be addressed through legal rules and institutions: global trade was legalized within the World Trade Organization (WTO, established 1995), mass atrocities and violations were addressed by international criminal tribunals and the International Criminal Court (ICC, established 1998). Tribunals were set for the law of the sea and for conciliation within the Organization for Security and Cooperation in Europe. The workload of human rights treaty bodies and regional courts exploded. Transnational commercial arbitration increased. Everyone was speaking about the "rule of law" in the international field and about the "constitutionalization" of international relations or some aspect of them. ${ }^{11}$

Francois Terre, Le positivisme juridique et Kant, in 2 Philosophie PolitiQue 159, 160-61, 166 (1992).

8 KANT, Universal History, supra note 3.

9 KANT, supra note 5.

10 See Martti Koskenniemi, On the Idea and Practice of Universal History with a Cosmopolitan Purpose, in 200 YEARS OF KANT (Heiko Sievers ed., forthcoming 2006).

11 For the debate among lawyers, see, for example, Jan Klabbers, Constitutionalism 
By the turn of the millennium, three phenomena appeared to overshadow these developments: "deformalization," "fragmentation" and "empire." ${ }^{12}$ By deformalization I mean the process whereby the law retreats solely to the provision of procedures or broadly formulated directives to experts and decision-makers for the purpose of administering international problems by means of functionally effective solutions and "balancing interests." By fragmentation? I mean the splitting of law into functionally defined "regimes" such as "trade law," "human rights law," "criminal law," "environmental law," "law of the sea," even "sports law," each geared to further particular types of interests and managed by narrowly defined expert competence. By empire I mean the emergence of patterns of constraint deliberately intended to advance the objectives of a single dominant actor, either through the law or irrespective of it.

The phenomena of deformalization, fragmentation, and empire emerge from the sense that traditional diplomats' law is failing to manage the problems of a globalizing world due to its excessive formality and rigidity and its failure to "adapt" to new regulatory needs. A shift is thus required from formal rules and institutions to the objectives or values "behind" them, far more real and important than their external manifestations. Do not remain enchanted by the legal form, critics say. Look behind rules and institutions. Assess costs and benefits. Streamline, balance, optimize, calculate. ${ }^{13}$

The takeover by the managerial mindset is reflected in the transformation of the vocabularies of power. The language of law is replaced by an idiolect of transnational regimes that enforce the most varied kinds of guidelines, directives, de facto standards, and expectations, so as to guarantee

Lite?, 1 INT'L ORG. L. REV. 31 (2004). One of the political theorists advocating world constitutionalism is Jürgen Habermas. See JÜrgEN HABERMAS, Hat die Konstitutionalisierung des Völkerrechts noch eine Chance, in DIE GESPALTENE WESTEN 113 (2004). For a representative collection of writings on international constitutionalism, see TOWARDS WORLD CONSTITUTIONALISM: ISSUES IN THE LEGAL ORDERING OF THE WORLD COMMUNITY (Ronald St. John Macdonald \& Douglas M. Johnston eds., 2005).

12 See also Martti Koskenniemi, Global Governance and Public International Law, 37 KRITISCHE JuSTIZ 241, 243-44 (2004).

13 The literature on the effects of globalization on law is too wide to be adequately reflected here. A useful collection of essays on specific aspects of these changes, however, is ERIC LOQUIN \& CATHERINE KESSEDJIAN, LA MONDIALISATION DU DROIT (2000). For a representative set of (American) essays on the various transformations, see THE Globalization of InTERnATIONAL LAW (Paul Schiff Berman ed., 2005). 
optimal effects. ${ }^{14}$ Formal rules yield to the amorphous "regulation" emerging from a heterogeneous variety of sources and actors. ${ }^{15}$ "Government" becomes "governance," and the language of legal "responsibility" is transformed into assessments of "compliance."16 "Disputes" become "management problems," and the question of lawfulness is replaced by that of "legitimacy," uncertainly situated between legal formality and political justice but reducible to neither and existing mainly as a feeling of legitimacy, a warm sense of contentment looking for no further justification. ${ }^{17}$

With new languages come the new experts who speak them. The managerial jargon of "legitimate governance" sets up an ersatz normativity that replaces the conservatism of law and the radical arbitrariness of justice, highlighting the instrumental role of law and public institutions in fulfilling desired objectives and the testing of authoritative decisions by reference to what target populations might "accept." The result is the imposition of empirical political science, thoroughly instrumental and committed, as a world tribunal assisting whoever is in charge.

In a book published in 2005 by Jack Goldsmith, professor at Harvard Law School, author of a memorandum on the transfer of prisoners to locations where they can be tortured submitted to the office of the U.S. Attorney General, and Eric Posner from the University of Chicago Law School, the authors argue that the traditional defence of international law, according to which most states abide by most international law rules most of the time, is characteristic of a lawyers' perverse habit of describing actual behavior as law. This claim, however, fails to explain why states do behave as they do. If, as these authors argue, behavior is caused and should be explained by reference to a "coincidence of interest and coercion," then the mention of "law" is an irrelevant decoration on what is merely a behavioral regularity. ${ }^{18}$

For these and other analysts, laws and treaties are bargains between

14 See, e.g., REgIME THEORY AND INTERNATIONAL RELATIONS (Volker Rittberger ed., 1995).

15 See, e.g., José E. Alvarez, International Organizations as LaW-MaKers (2005); The EMERgEnCE of Private Authority in Global Governance (Rodney Bruce Hall \& Thomas Biersteker eds., 2002).

16 See, e.g., LEGALIZATION IN WorLd POLITICS (Judith Goldstein et al. eds., 2001); LAW and Governance in Postnational Europe: Compliance beyond the NATIONSTATE (Michael Zürn \& Christian Joerges eds., 2005).

17 On this, see also Martti Koskenniemi, Legitimacy, Rights and Ideology: Notes Towards a Critique of the New Moral Internationalism, 7 AssociaTiOns 349, 349-74 (2003).

18 Jack Goldsmith \& ERic A. Posner, The Limits of InTERnational LaW 23-43 (2005). 
rational egoists seeking to resolve co-ordination or co-operation problems so as to minimize transaction costs. ${ }^{19}$ Compliance does not follow from "binding force." This is a metaphysical abstraction. Instead, it comes about "because [States] fear retaliation from the other state or some kind of reputational loss, or because they fear a failure of coordination. ${ }^{20}$ For example, the provisions on the use of force in the U.N. Charter constitute a bargain states once made to receive protection. That bargain is now undermined because weapons of mass destruction have come into the possession of terrorists. For states as rational egoists, therefore, the "costs of strict adherence to the U.N. Charter in a world of new security threats" have just become too great, ${ }^{21}$ as pointed out by John Yoo, author of another torture memorandum submitted to the U.S. Government. Goldsmith and Posner note: "[W]e have explained the logic of treaties without reference to the notions of 'legality' or pacta sunt servanda or related concepts," ${ }^{22}$ and they conclude with relish: "There is a more sophisticated international law literature in the international relations subfield of political science." 23

\section{III.}

This critique of law and international institutions has real bite. Indeed, it is often obscure to lawyers what makes states act as they do. As instruments for advancing preferences, customary international law or the institutions of the diplomatic system, including the multilateral treaty or the arbitral tribunal, are scarcely models of effectiveness. But should that be the main perspective for assessing them?

The idea of law as a "bargain" between rational egoists looking for "compliance" relies on a wholly dogmatic notion of agency (actor as "egoist") with determinate and definable "objectives" and "interests," and on a specific view about the meaning of the social facts to which this notion should be applied. This is not the place to engage in a detailed critique of the normative import of empirical social science, well known since Kant's first formulations of it against the mechanistic empiricism of early modern

19 Id. at $84-85$.

20 Id. at 90.

21 John C. Yoo \& Will Trachman, Less than Bargained for: The Use of Force and the Declining Relevance of the United Nations, 5 CHI. J. INT'L L. 379, 384 (2005).

22 GOLDSMITH \& POSNER, supra note 18, at 90.

23 Id. at 15. 
natural law (especially in Hobbes and Pufendorf). ${ }^{24}$ My analysis here is confined to the extent of the similarities between the difficulties confronting the managerial mindset and those faced by its nemesis, legal formalism, in four aspects of its argument.

First, its notion of "interest" or "objective," which presumes homogenous actors with full knowledge of their environment and a stability of preferences analogous to the legalist "will" theory of contract and legislation, totters between a psychological view blind to the social conditioning of interest-formation and a naturalistic (and authoritarian) theory of "objective interests." Second, the translation of ("raw") interests or objectives into policy preferences is just as indeterminate as the translation of "will" into "rules" in formalist legislation. The only difference hinges on how to understand the translation: political decision or expert calculation? Third, the application of "policy" to individual instances of practice is hardly different from rule- application. Like rules, policies come with exceptions and counterpolicies and are applied in "contexts" that can be described in any number of ways. The interesting question, then, is no longer "what policy" but quis judicabit? And fourth, the search for "compliance" assumes full knowledge of what there is to comply with, namely, of the "behavioral standard" (i.e. "rule"). But as every lawyer knows, this is where the problems start. ${ }^{25}$ All will claim they are complying - perhaps in an unorthodox way, applying the exception instead of the rule or the counter-principle for the principle - and will challenge anyone's power to even suggest otherwise. Paradoxically, the managerial mindset assumes the absolute determinacy of the directives it uses to attain regime-objectives, which must be not only semantically determinate but must also form a stable and harmonious whole, immediately translatable into policy for future cases. This is more than formalism, it is a caricature of nineteenth century Begriffsjurisprudenz.

The same rejoinder is valid for the retort that management is not formalism but balancing and costs- and-benefits calculation. What items go into the

24 The normative nature of empirical social sciences is a classic topic of debate and listing the arguments here yet again is slightly embarrassing. For those who have not yet had their determinacy crisis, a good place to prepare for it might be, for instance, The Positivist Dispute in German Sociology (Theodor W. Adorno et al. eds., 1977).

25 This is also pointed out in Michael Zürn, Law and Compliance at Different Levels, in LAW AND Governance in Postnational EuRope: Compliance BeyOnD THE NATION-STATE, supra note 16, at 1, 8-9. See also Benedict Kingsbury, The Concept of Compliance as a Function of Competing Conceptions of International Law, 19 MiCH. J. INT'L L. 345 (1998). 
"balance"? Will the preferences of those not present be included, and how will they all be "weighed" against one another? When do the "costs of strict adherence" really become too great, and for whom? The problem is not that such questions cannot be answered. Of course they can. But when they are answered from within a managerial mindset, a structural bias emerges, a consistent bias for the best values of the relevant expertise: when in doubt, decide in favor of, for example, "free trade," "clean environment," "financial strictness," "preventing over curing," "safe over sorry," "security over chance" (but also "right over security" in rights-regimes), and so forth. ${ }^{26}$

In other words, when the managerial mindset in its formalistic mode imagines itself as law, it becomes a particularly unreflective version of legal literalism. When thoroughly managerialized, it turns into rule by the experts managing those practices, that is, into unreflective support of the structural bias within a particular expert discourse. Ancien régimes, after all, were also regimes, and the rule of law was imagined by Kant and other liberals against all that.

Contrary to the managerial mindset, a Kantian perspective does not see the law as an instrument for explaining behavior or advancing preferences. Kant's critique of early modern natural law as it had been articulated by Grotius, Pufendorf, and Vattel, targeted the reduction of law into a system for calculating happiness and constraint on the basis of an empirically defined "human nature" so as to produce an optimally robust social order. ${ }^{27}$ As I have argued elsewhere, the idea of global law as a system of coordination between functional regimes creates a de-territorialized equivalent of Carl Schmitt's ius publicum Europaeum, a naturalized division of the world into de facto powerful orders hierarchically organized so as to guarantee maximal effect. ${ }^{28}$ For the managerial mindset, globalization means imagining the world

26 These are, I suppose, what Duncan Kennedy dubs the ideological stakes or adjudication. Of course, Kennedy's analysis of the simultaneously policyoriented and formalistic nature of (liberal) adjudication and adjudication theory is equally applicable in the above analysis. See DunCAn KenNEDY, A CRITIQUE OF ADJUDICATION (FIN DE SIÈCLE) 39-70 (1997) (ideological stakes); id. at 97119 (policy argument). On structural bias, see also MARTTI KOSKENNIEMI, FROM APOlOGY TO UtOPIA: THE STRUCTURE OF INTERNATIONAL LEGAL ARGUMENT 600-15 (reissue with a new Epilogue, 2005).

27 Kant, Perpetual Peace, supra note 3, at 103. For Kant's critique of early modern natural lawyers, see SIMONE GOYARD-FABRE, CRITIQUE DE LA RAISON JURIDIQUE 124-35 (2004).

28 Martti Koskenniemi, Global Legal Pluralism: Multiple Regimes and Multiple Modes of Thought, Keynote Speech, Harvard University (Mar. 5, 2005), available at http://www.valt.helsinki.fi/blogs/eci/PluralismHarvard.pdf. See also 
of regimes as the modernized equivalent of seventeenth and eighteenth century absolutist Europe.

IV.

International lawyers have tried to respond to deformalization, fragmentation, and empire by resorting to a vocabulary of institutional hierarchies and fundamental values. In practice, this device has often seemed little more than an effort to imagine public diplomacy and the institutions of the United Nations and other intergovernmental organizations in the image of the (European) nation-state. As an architectural project, constitutionalism, just like the rule of law, is compatible with many kinds of politics and it is far from clear who might currently stand to benefit from a return to traditional multilateralism. Deformalization and fragmentation respond to problems inherent in uniform rules and single hierarchies and cannot be wished away. In an important sense, "empire" is also a constitutionalist project, a counterweight to deformalization and fragmentation, and the practical question seems to boil down to whose constitution one might have reason to prefer, the American or the European. ${ }^{29}$

But constitutionalism is not necessarily tied to any definite institutional project, European or otherwise. Irrespective of the functional needs or interests that laws may seek to advance, a Kantian view would focus on the practice of professional judgment in applying them. Less than an architectural project, constitutionalism would then be a programme of moral and political regeneration. This is what I mean by the description of constitutionalism as a "mindset."

To illustrate the constitutional mindset at work, let me refer to the 2002 request of the U.N. General Assembly from the International Law Commission, a subsidiary body of 34 public international law "generalists": to conduct a study on "fragmentation," i.e., the breakdown of the substance of general international law into allegedly autonomous, functionally oriented, "self-contained" regimes. How independent had these become? Had globalization, and in particular the proliferation of international law-

Martti Koskenniemi, The Empire(s) on International law: System Change and Legal Transformation, 8 AUSTRIAN REV. INT'L \& EUR. L. 61, 61-68 (2003).

29 I have elaborated this more in Martti Koskenniemi, International Law and Hegemony: A Reconfiguration, 17 CAMBRIDGE REV. INT'L AFF. 197, 197-218 (2004). 
applying agencies, created a "risk" of fragmentation, namely, overlapping judgments, forum-shopping, normative conflict, and "constitutional crisis"?

The Commission set up a Study Group to examine these concerns. ${ }^{30}$ Although its mandate covers "deformalization" only by default (namely, insofar as it leads to the emergence of pockets of "special law") and does not include "empire" (although empire being "empire" can never disappear altogether), its conclusions, to be presented in the summer of 2006, will still be relevant to both. These conclusions are more important for the kind of perspective they bring into the debates than for their practical recommendations.

The Group has found that international practice has never treated specialized rule-systems as independent from the rest of the law. Somehow, the very idea of international law has implied a systemic view of the materials: the application of any one rule presumes the presence of principles about how to determine the rule's validity, whom it binds, how to interpret it, and what consequences might follow from its breach. You could not just take one bit and leave the rest aside: il n'y pas de hors-droit. Or, in the words of a claims commission requested in 1928 to apply a treaty in the absence of any indication on how this should be done:

Every international convention must be deemed tacitly to refer to general principles of international law for all the questions that it does not itself resolve in express terms and in a different way. ${ }^{31}$

This seems almost self-evident. No lawyer will refuse to find states as states, or ask for evidence for the rule of audiatur et altera pars merely because the immediately applicable law is silent about such matters. These are structurally given, not positively enacted or incorporated. In its very first case, the Appellate Body of the World Trade Organisation (WTO) observed that WTO agreements "should not be read in clinical isolation from public international law," and later specified that "[c]ustomary international law applies generally to the agreements between WTO members." 32 A legal regime such as the European or Inter-American Human Rights Convention makes constant reference to general international law without

30 For the work of the Study Group so far, see International Law Commission, Report on the Work of Its Fifty-Seventh Session, ch. XI, U.N. Doc. A/60/10 (Aug. 5, 2005).

31 Georges Pinson Case (Fr. v. Mex.), 5 R. Int'l Arb. Awards 327, 422 (1928).

32 Appellate Body Report, United States - Standards of Reformulated and Conventional Gasoline, 16 WT/DS2/AB/R (Apr. 29, 1996); Panel Report, Korea Measures Affecting Government Procurement, $\mid 7.96$, WT/DS163/R (May 1, 2000). 
any act of incorporation. ${ }^{33}$ The International Criminal Tribunals on the former Yugoslavia and Rwanda repeatedly apply law that originates beyond their constituent instruments. Even when the law appeared to step aside so as to leave room for expediency, as was arguably true when the International Court of Justice affirmed in the 1992 Lockerbie case that Security Council decisions override the rights of states under particular treaties, it did so as an inference from Article 103 of the U.N. Charter. ${ }^{34}$ The intense inter-war debates about the limits of international law were perfectly capable of accommodating the view that, whatever those limits were, they were set and policed by law. ${ }^{35}$

We may sometimes catch a glimpse of the legal proprium in a negative light. The trade experts negotiating the 1995 WTO treaties were so wary of importing law into the application of what was to be a fully functional trade regime that they tried to erase any suggestion of a legal system from the relevant (legal!) instruments by establishing only a "body," with "members" issuing "reports" that were to be "adopted" by the states parties. ${ }^{36}$ Remarkably, however, the Appellate Body (AB) is today treated as a "court" and its members as "judges," and its reports are read at government offices and universities as "judgments" whose "binding force" is hardly undermined by the (remote) possibility that WTO members might unanimously decide to set them aside. But a tension persists between "lawyers" and "trade experts," focusing on the extent of the independence asserted by the AB: to what extent does it follow functionally "proper" free trade principles? ${ }^{37}$

Law has a centripetal pull, the ILC study will suggest. Legal words cannot be separated from the language in which they lead their life. They operate only in the context of other legal words and of a professional grammar

33 See, e.g., Luzius Caflisch \& Antonio Cancado Trindade, La convention américain et européenne de droit des l'homme et le droit international général, 108 R.G.D.I.P. 5, 5-62 (2004).

34 Questions of Interpretation and Application of the 1971 Montreal Convention Arising from the Aerial Incident at Lockerbie (Libyan Arab Jamahiriya v. U.K.), 1992 I.C.J. 3, 15 (paras. 39-40, discussing U.N. Charter art. 103).

35 See in this regard especially HANS MorgenthaU, DIE INTERNATIONALE RECHTSPFLEGE, IHR WESEN UND IHRE GRENZEN (1929) and HERSCH LAUTERPACHT, THE FUNCTION OF LAW IN THE INTERNATIONAL COMMUNITY (1933).

36 For the view that trade rules simply are not "binding" as traditional international law, see Judith Hippler Bello, The WTO Dispute Settlement Understanding: Less is More, 90 AM. J. INT'L L. 416, 416-18 (1996).

37 See Joseph Weiler, The Rule of Lawyers and the Ethos of Diplomats: Reflections on the Internal and External Legitimacy of WTO Dispute Settlement (Harvard Jean Monnet, Working Paper No. 9/00, 2000), available at http://www.jeanmonnetprogram.org/papers/00/000901.html. 
about how they are used in relation to each other. The message will be that there is really nothing novel in fragmentation. The international context, perhaps like "modernity" tout court, was always "fragmented." Through recourse to various well known professional techniques, conflicts between rules emanating from different regimes may be resolved, formal rules "deformalized" so as to adapt them to changing circumstances, and de facto ("imperial") power deferred to. Even in the absence of a formal constitution, a practice does exist of "constitutionalizing" international relations by constant adjudication between rules and rule-systems, deciding on institutional powers of international bodies, and formulating legal "principles" out of scattered materials. The report of the Study Group will thus illustrate the constitutional mindset at work.

But although the report will show that the law has the resources to deal with technically novel phenomena and with conflicts between functional regimes, it will stop short of suggesting how any particular technical or economic or environmental problem should be resolved. No definite hierarchies will emerge from the study, only illustrations of how such hierarchies were set up in the past. ${ }^{38}$ Even if the law offers a solution to every problem, we cannot know what that solution is. After all, rules do not spell out the conditions of their own application.

The result, therefore, could seem insufficient to those hoping to undo deformalization, fragmentation, or empire through firm hierarchies or definite policy suggestions. What is the worth of a "constitution" merely saying that, when problems emerge, it can be used to resolve them, without specifying how they should be resolved? Is environment more important than trade? Or vice-versa? Or, in a more policy-oriented vocabulary: why would anyone wish to allocate the solution of any problem to the "law" if no one can predict what this means in terms of outcomes, as opposed to allocating it to a functional regime where the objective will always be the optimal result from these functions' perspective?

These questions emerge, however, from a familiar hubris, present in both textual (formalist) and non-textual (anti-formalist) variants: the assumption that a right ("lawful," "valid," "optimal," "effective") solution already exists

38 For the first section of the Report, see International Law Commission, Study Group on the Fragmentation of International Law, Preliminary Report: The Function and Scope of the Lex Specialis Rule and the Question of Self-Contained regimes, U.N. Doc. ILC(LVI)/SG/FIL/CRD.1 \& Add.1 (May 4, 2004) (prepared by Martti Koskenniemi, Chairman of the Study Group). The Final Report is now available as Fragmentation of International Law: Difficulties arising from the Diversification and Expansion of International Law, U.N. Doc. A/CN.4/L.686 13 (Apr. 2006). 
somewhere, and the lawyer's task is just to find it and apply it. This hubris is akin to the one Kant detected in early modern natural law, and indeed in "dogmatism," which used pure reason to capture the (noumenal) world "without previous criticism of its own powers." ${ }^{39}$ If there was room for natural law, as there obviously was, it could only relate to the form in which reason directs itself toward the external world, not to any content that it could report to consciousness. ${ }^{40}$ Knowledge of the law, like any other knowledge, was not about the facts of an external (textual or natural) reality but about the application of procedures of reasoning to the available materials, aiming toward conclusions that had the best chance of impartial, perhaps even universal, approval.

This shift, from legal materials to examples of the use of legal judgment in particular cases, will be the principal contribution of the study by the International Law Commission to the debates on international law's fragmentation. It will corroborate the finding in a number of classic studies on the problem of "gaps in law": even where legal materials run out, legal reason will continue to operate ${ }^{41}$ It is always possible to decide a case, however intractable, new, or complex it may seem. To account for this experience, liberal legal theory has developed a number of techniques for justifying legal decision-making in "hard cases." In particular, it has turned to the Geistenswissenschaftlich vocabulary of hermeneutics and interpretation, the justification of juristic decision-making by its aesthetics, the search for "coherence" or "fit" between the novel case and the legal tradition..$^{42}$ There is nothing wrong with this. This is what traditions $d o$ : they try to accommodate new phenomena in patterned, familiar understandings, seeking to balance reverence for the past with openness to the future, with innovators sometimes rejected as degraders, sometimes celebrated as regenerators. The task that deformalization, fragmentation, and empire set before public international law is nothing more than an invitation to professionals in this field to apply their public-law oriented "constitutional" mindsets to new technical

39 KANT, supra note 1, at 24.

40 KANT, supra note 2, at 23-24 (Introduction, § B, 6:229-30).

41 See, e.g., Hersch Lauterpacht, The Development of International LaW By the InTERNATIONAL COURT (2d ed. 1956); see also LuCIAN SiORAT, LE Problème des Lacunes en Droit International Public (1959); Ulrich FASTENRATH, LÜCKEN IM VÖLKERRECHT. ZU RECHTSCHARACTER, QUELLEN, SYSTEMZUSAMMENHANG, METHODENLEHRE UND FunKTIONEN DES VÖLKERRECHTS (1991) (especially at 213-51).

42 See, in particular, RONALD DWORKIN, LAW's EMPIRE (1986). 
problems. This is an invitation to renewal and innovation, no doubt, but nothing that would be dramatically difficult or even alien.

This response may not satisfy the managerial mindset, however, which wants to say more, namely, that the very tradition of public international law is part of the problem and that, no matter how "constitutional mindsets" deal with novel problems, they will fail to attain the good outcome precisely because they are "constitutional" and thus limited by their "formalism" and their "utopian" view of present legal institutions as somehow always automatically beneficial. In the remainder of this Article, I will try to articulate the case for the constitutional mindset that is not a priori bound up with any determinate institution, a mindset building on a tradition understood from a Kantian perspective as a project of "freedom." The best way of doing this is to juxtapose this mindset with the ideas of managerial governance that emerged from the eighteenth century experience of capitalism, secularisation, and modernity targeted in Kant's critical philosophy.

\section{V.}

The part of Kant's lecture from 1780 that I quoted above runs in toto as follows:

All animals have the faculty of using their powers according to their will. But this will is not free. It is necessitated through the incitement of stimuli, and the actions of animals invoke a brute necessitas. If the will of all beings were so bound to sensuous impulse, the world would possess no value. The internal value of the world, the summum bonum, is freedom in accordance with a will that is not necessitated to action. Freedom is thus the inner value of the world. ${ }^{43}$

In this Kantian image, the managerial mindset renders human beings as unfree animals. If I always act strategically in order to realize my interest, and if my interest is defined in accordance with my pleasure, then there is really no "I" acting at all, only a replaceable cog in the functional machine that is indeed the regime of my desires. I am unfree because I am coerced without being under a legal obligation, that is, without the

43 Cited in GuYER, supra note 4, at 129. 
legal proprium.$^{44}$ Obligation can attach to a directive only by its imposition through an authoritative will that may originate in any powerful source. For freedom to be a reality, however, it must come from within me, and not from me as a passive navigator between pains and pleasures. ${ }^{45}$ In order for my will to be free, I must be able to choose to will in accordance with universal law. This is the crux of the Kantian formulation of the constitutionalist mindset: autonomy, and ultimately freedom, can only exist in relation to law conceived universally.

International lawyers have often been struck by the passage in Perpetual Peace in which Kant dismisses the natural and international law tradition of Grotius, Pufendorf and Vattel as "leidige Tröster," miserable comforters. ${ }^{46}$ Kant uses this phrase to argue that law could be built on self-love only at the cost of collapsing human society into the status of an animal farm. To think of public power in utility-maximizing terms can neither account for respect for human beings nor for the emergence of the kingdom of ends. If individuals, and by extension states, treat each other as instruments of pleasure, as is true of the rational egoists of natural law or present-day law and economics, ${ }^{47}$ the result may be an equilibrium that is at best bearable though unlovely, such as that of the present European Union, in constant danger of slipping toward the capture of the state by special interests. Kant lacked the critique of "governmentality" when he was attacking the preceding generation of natural lawyers, who had been trying to build a political theory on the quintessentially modern notion of the homo economicus. ${ }^{48}$ But he saw no less clearly than Foucault the effects of the turn from sovereignty to the disciplinary power of economics, technology and science. Is the alternative to scepticism really the reduction of human beings to functional structure, Leviathan understood as a calculation machine?

The critique of natural law as a critique of technological reason is certainly rooted in Europe, and that critique may bring both light and darkness to the

44 Cf. Mary Gregor, Kant on Natural Rights, in KanT AND POLITICAl PhILOSOPHY 50, 52-61 (Ronald Beiner \& William James Booth eds., 1993).

45 See, e.g., ImMANuEl Kant, Groundwork OF THE Metaphysics OF Morals 40-41 (Mary Gregor ed., Mary Gregor trans., Cambridge Univ. Press 1998) (1785) (4:433).

46 KANT, Perpetual Peace, supra note 3, at 103.

47 The character of law \& economics as modern natural law is discussed in BENOÎT FrydMAN \& GUY HAARSCHER, PHILOSOPHIE DU DROIT 67-97 (1998).

48 Michel Foucault, NAissanCE DE LA Biopolitique: Cours Au College DE FranCE 1978-1979, at 271-329 (2004). Foucault listed Kant among those who participated in this by canvassing a teleological "plan of nature" that would bring about world unity (under European leadership) by the creation of global markets though global law. $I d$. at $57-60$. 
world, as Europeans know only too well. Kant's "Copernican revolution" may have contributed to the release of some breaks that, had they been in place, might have lessened the scale of twentieth-century European catastrophes. But (pace Foucault) Kant is innocent of Europe's later moral failures. His notion of freedom, which belongs to the original Enlightenment project seeking to liberate human beings from their self-imposed immaturity, remains as valid now as it was two-hundred years ago. From that perspective, strategic action, game theory, and the balancing of stakeholder claims in order to reach the Pareto optimum will always involve a Faustian pact. Costs and benefits can never be calculated so as to take into account the transaction costs of turning to calculation in the first place, namely, the cost of freedom.

But what is "freedom"? No doubt, reference to the freedom-enhancing quality of the law is an offshoot of eighteenth-century rationalism, which is highly vulnerable to critique. For instance, according to standard liberal theory, the rule of law is supposed to safeguard freedom by binding public officials to predictable forms of behavior so that individuals may plan their lives as they wish. ${ }^{49}$ But if the critique of legal indeterminacy is right, that is, if legal rules do not spell out the conditions of their application, there is no guarantee of predictability or, where predictability does exist, no guarantee that it would not result from political bias rather than from the law. Of course, patterns do emerge and institutional behavior does become predictable, and this is celebrated under the ideology of the rule of law. ${ }^{50}$ And yet, as critics note, mere uniformity is not per se beneficial or, at least, not necessarily more beneficial than the rule of an enlightened, if capricious, prince.

An alternative could be offered to Kant's explanation of the freedomenhancing nature of the law. If freedom means individual autonomy and self-determination, namely, recognizing only the authority of one's own will, there must be a technique for communicating that will between individuals on the one hand, and between individuals and the public power on the other. Law is needed for legislation to exist, and legislation is needed for self-determination to be possible. Law's virtue does not lie only in law-application. It resides equally in legislation as the expression of a community's self-determining will. It was not for nothing that what Kant celebrated in the French Revolution was precisely the way it expounded

49 E.g., F.A. HAYEK, THE CONSTITUTION OF LiBERTY (1960) (especially at 133).

50 For a general overview, see BRIAN Z. TAMANAHA, ON THE RULE OF LAW: HiSTORY, POLITICS, THEORY (2004). 
"the right of every people to give itself a civil constitution of the kind that it sees fit, without interference from other powers." ${ }^{51}$

The predictability or stability brought by law is not what made Kant a legalist. Clearly, the ancien régime had been stable and had acted predictably for a long, indeed too long a time. It may have acted arbitrarily too, but that was not the main problem. The problem was its consistent reliance on social hierarchy, and the suppression of freedom from the bulk of the population. This is why the first article of the project on perpetual peace called for the establishment of republican (i.e. representative) government. ${ }^{52}$ And this is what resonates in the current experience of globalization, and in the sense in which fragmentation, deformalization, and empire seem to undermine individual autonomy and communal self-determination. In fragmentation, law emerges from expert-guided "regimes"; in deformalization, it transforms into administrative compromises between powerful stakeholder groups, and in "empire," it collapses into domination. The worry about new global law reflects concerns about the absence of structures of political representation, contestation, and accountability, of a public sphere institutionally linked to global power. The present concern about freedom spells worries about autonomy, understood as self-legislation. Whatever the managerial mindset has to say about the difficulties of effective governance today fails to address the sense that these difficulties are undermining freedom, in the sense of leading one's life only under the authority of one's own (good) will.

To be sure, the vocabulary of freedom has enjoyed an ambivalent career on both sides of the Atlantic. The complexity of the Kantian, or perhaps the German, idea ${ }^{53}$ of freedom as fidelity to the law may appear as an invitation to authoritarianism. ${ }^{54}$ It is interesting to see how French inter-war social and legal thought, for example, derived German aggression from Kant, sometimes even from Luther, without worrying too much about fine distinctions. ${ }^{55}$ From this perspective, the freedom promised by the Enlightenment was always too heavy. As actual individuals collapsed under its weight, they became easy material for uncritical co-option into whatever collective romance was being

51 Immanuel Kant, The Contest of Faculties, in Political Writings, supra note 3, at 182.

52 KANT, Perpetual Peace, supra note 3, at 99-102.

53 Leonard Krieger, The German Idea of Freedom: History of a Political TRADITION (1957).

54 As suggested, for example, in Martin Wight, Foreword to Four Seminal THINKERS IN INTERNATIONAL THEORY 67-71 (Gabriele Wight \& Brian Porter ed., 2005).

55 See, e.g., Louis Le Fur, GUERre JUSTE ET JUSTE PAIX 29-38 (1920). 
offered instead. Thanks to Kant, these critics were saying, that co-option could always be described in terms of (positive) freedom.

In the New World, freedom was a more straightforward notion. Even to think of the state as the fullest realisation of freedom, as Kant and other Europeans did (and still do), was the epitome of confused, dangerous dogma. ${ }^{56}$ True, it may be nice to have clean parks and public spaces, with unbroken benches and without a beer ad blocking the view of the lake. But these are no match, politically speaking, to the freedom to drink beer, or to sell it, and then if a drunk but free individual throws the bench into the lake, why would you mind? If in Europe, freedom was devoured by law, in the United States, freedom tends to devour itself.

How so? Again, through hubris, such as the hubris of "infinite freedom" for the Iraqis. But freedom cannot be "infinite. ${ }^{\text {"57 }}$ This is the wish to eat an infinite number of hamburgers without being disturbed by the awareness of what it will do to your physical constitution. Political freedom untainted by knowledge turns power into an apparently unending source of instant gratification with tragedy looming just around the corner. In the early spring of 2003, I was in New York following the march to war when an "expert" explained on Fox TV that U.S. soldiers should behave with dignity when Iraqi women throw candy at their feet, since this is the traditional Iraqi way of greeting liberators. The prospect of being seen as "heroes" must have so warmed the hearts of the audience that it stunned the mind against everything we know or may suspect of other societies.

There would be no candy. Instead, the "illegality" of the war would become a key point in the worldwide opposition to it. Why? Because although it was carried out in the name of "freedom," it violated the key (Kantian) sense of freedom as self-determination and autonomy. ${ }^{58}$ The special scandal of the war did not lie in the fact that its justifications turned out to be lies and that, even if they had been true, they might not have made a persuasive case for war. The scandal was the cynical manner in which the process to war brushed aside any need to treat other people as free, autonomous, and deserving an equal hearing in the common vocabulary of the law of peace under the United Nations Charter. An arrogant act of imperial hubris, it could only lead to unfreedom.

56 Which is why so many liberal Kantians today oppose the State.

57 As pointed out in TERRY EAGLETON, HOLY TERROR 68-88 (2005).

58 I have treated the "special scandal" of the Iraqi war and the universalism in response of the civil society at greater length in Martti Koskenniemi, What Should International Lawyers Learn from Karl Marx?, 17 LEIDEN J. INT'L L. 229, 242-246 (2004). 
The war propaganda spoke about bringing happiness to Iraq. But Kant, of course, held that moral law could not be based on a (Hobbesian) search of happiness, for it could then not be universal. ${ }^{59}$ People derive happiness from different sources and we have no automatic access to the happiness of others; indeed, to presume we have violates their autonomy. This was certainly one of the bases for Kant's view that morality pronounced an absolute veto on war and, more specifically, his view that one of the "Preliminary Articles on Perpetual Peace" should read: "No state shall forcibly interfere in the constitution and government of another state." ${ }^{60}$ The Kantian notion of freedom was developed with vivid awareness of the limitations that an external cognitive, political, and moral world impose on freedom. The point of the critique of pure reason was precisely to undermine hubris, to outline the respective jurisdictions of reason and faith by producing their coterminous limit. Freedom was what was not limited by what we can know and, as Kant never tires of reminding us, first of all we should know. Sapere aude! This was not just a practical instruction for scientists, but a moral principle applicable to all.

But Kantian freedom is also limited by the moral law. Indeed, it is an effect of that law. Freedom unrestrained by the moral law sees no obstacle, for instance, to legislation allowing torture, as long as instrumental justification can be adduced: the bomb is ticking and torture might save lives. For a Kantian, practices of torture are the moral equivalent of eating too many hamburgers; the one corrupts the soul just as surely as the other destroys the body, which of course appears to prove the very point the managerial mindset always makes: you are an unredeemed metaphysician! Not to torture, it suggests, is irresponsible: how many innocent must be sacrificed to the moral absolutism of some?

No doubt, absolutists can be reduced to moral relativism through scenarios of ticking bombs and raped mothers. In fact, it is just as simple to turn relativists into absolutists by pointing out that, when the time of decision comes, one scale of values, out of all the alternatives still available a moment before, must be vindicated at the exclusion of others. Absolutism and relativism, principles and calculations, are positions impossible to sustain for any length of time. Kantian lawyers may have tended to err on the side of absolutism, but this becomes pathological only if they simultaneously fail to take seriously the antinomy of law and of judgment and believe that their

59 KANT, supra note 45, at 8-9, 19-20 (on the limits of understanding to grasp what brings "happiness"); KANT, supra note 2, at 9-10.

60 KANT, Perpetual Peace, supra note 3, at 96. 
(proper) constitutional rigorism prevents them from a close analysis of the particular cases they have to judge.

\section{VI.}

"All right," says the expert, "so you say the law comes first, and only through the law can we be free. But you have also said, correctly, that 'the law does not spell out the conditions of its own application.' And still you seek commitment to institutions and legal forms. Why? If the law is indeterminate, then surely you should simply turn to the consequences of alternative choices, analyze the costs and benefits, and then decide. To tie yourself to the form of the legal is to remain bound by pre-modern mystique; under the cover of constitutionalism, you are led into decisionism. Behind the figure of Hans Kelsen lurks the shadow of Carl Schmitt."

Neither Kant nor Kelsen are concerned with legal hermeneutics, and this may seem strange. For Kelsen, determining the content of the legal norm was a political question, a view that mainstream liberal theory has consistently seen as one the main weaknesses of the pure theory of law, however much Kelsen may have thought of his formalism as a political project. ${ }^{61}$ To locate the power of his project, which I see as an effort to institutionalize a constitutional mindset to contest the use of power, we must first sketch what it had targeted.

In Weimar jurisprudence, two types of managerial mindset competed for state power. One saw the state as an instrument for bargaining between special interests, a calculating machine enabling different social groups to divide available resources between them. Another saw the state per se as representing an ethos or a founding principle (nomos) that the state was meant to realize. State law was about something beyond itself, as well as an instrument for managing state power to fulfil these external objectives or functions. For Kelsen (or indeed for Kant), the task was to construe a "strong state," able to resist these two threats without becoming an "authoritarian state."

61 See Jochen von Bernstorff, Der Glaube an Das Universale Recht: Zur VÖLKERRECHTSTHEORIE HANS KELSENS UND SEINER SCHÜLER (2001). The story of the political weakness of Kelsen's "pure theory" is well told in DAVID DYZENHAUS,

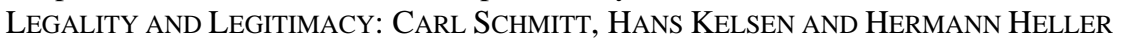
IN WeIMAR (1997) (especially at 157-60); see also MARTTI KosKenNiEMI, THE GENTLE CiVILIZER OF NATIONS: THE RISE AND FALl OF INTERNATIONAL LAW 18701960, at 238-49 (2001). 
Rational choice, strategic action, and the search for "compliance" in international relations departments and law schools pose similar types of "realist" challenges to international law: to articulate the concerns of the new managerial classes on the one hand, and to streamline the imperial machine on the other. They describe a world of political conflicts over resources, rights, and conditions for spiritual and material well-being as a world of technical management problems. Where law enables contestants for resources to express their claims in terms of rights and of the accountability of public officials, managerialism sees only private interests poised against one another, suggesting that all the regime needs is even more fine-tuning by better expert analysis.

Like the expert on Fox TV, these new realists, in their hubris, believe in the power of their predictive and explanatory matrices and think that words such as "power," "bargain," "costs and benefits," or "legitimacy" mark out entities in the empirical world that would automatically guide policy. But since expert systems are no less indeterminate than law, this move only institutionalizes an anti-political, technical mindset that, under the cover of seeking effectiveness, looks no further than the next internal audit and the prospects for the next promotion: $m y$ success as the criterion of the world's happiness.

In the Appendix to Perpetual Peace, his eyes firmly fixed on France, the end of Terror, and the establishment of the Thermidorean constitution, Kant makes a distinction between the "political moralist" and the "moral politician." 62 The former, he writes "makes the principles subordinate to the end." 63 These ends have no independence from the ends of some people, namely, those managing the regimes and their academic advisers. Kant would stress the degree to which political moralists are enchanted by the force of their soi-disant "realism," their prudential vocabulary of power that always enables them to find a strategic consideration to justify putting other people into harm's way, thus "placing man into the same class as other living machines, which only need to realise consciously that they are not free beings for them to become, in their own eyes, the most wretched of all earthy creatures." 64

Having outlined the moral necessity of shifting relationships between nations from the state of nature to a federation that would secure freedom

62 For this link, see Andre Tosel, KAnT Revolutionnaire: Droit ET POLITIQue 19-21 (1990).

63 Kant, Perpetual Peace, supra note 3, at 118-21.

64 Id. at 123. 
for all of them, and having insisted that states must "adapt themselves to public coercive laws," ${ }^{65}$ Kant says nothing about how or by whom those laws should be administered, either in Perpetual Peace or in his Rechtslehre a few years later. He only discusses the "moral politician," who focuses on how to treat others as ends and not as means, that is, relinquishing the utilitarian vocabulary of early natural law that was the apology for absolutism. Kant, of course, did not think that fidelity to the law meant fidelity to any particular substance but irrespective of such substance; on the other hand, since he leaves the determination of substance to the judgment of the law-applier, he also liberated the latter to construe the meaning of the law to be applied.

Kant probably refrained from proposing a legal hermeneutics because it could have no power to bind law-appliers, whose moral duty is to judge for themselves what the principles of universality and freedom might require in a real world of conflict and contestation. Kant has nothing to say about technical lawyers, apart from dismissing some of them as "miserable comforters." But he has much to say about "moral politicians," whose task it would be to administer the federal pact so that, in due course, it would lead to perpetual peace. Moral politics and legal practice cannot be separated. Law is simply the name for the external institutions that administer what is a moral-political project. ${ }^{66}$

\section{VII.}

Thinking of constitutionalism as a mindset instead of as architecture implies a kind of Copernican turn in legal theory. Mere constitutional architectonics, as Kelsen was to experience personally, provides a poor guarantee for freedom. Whereas early modern natural lawyers thought of constitutions as mechanisms of control and of constitutional debates as discourses of power, Kant sought to articulate their historical specificity against such "dogmatisms." What was the difference between the French revolutionaries and the representatives of the ancien régime? What was the significance of a people in 1789 giving "itself a civil constitution of the kind it sees fit" instead

65 Id. at 105.

66 The view of Kant as seeking internal moral regeneration, and thus prolonging the tradition of school metaphysics against the externally oriented civil philosophy of Pufendorf and Thomasius, is discussed rather interestingly, even if perhaps one-sidedly (there are practically no references to Kant's openly political writings) in Ian Hunter, Rival EnLightenments: Civil and Metaphysical Philosophy IN EARLY MODERN GERMANY 274-376 (2001). 
of receiving one from a benevolent tyrant? Surely the difference between the Revolution and the counter-revolution was not exhausted by the fact that one was successful and the other was not. The Revolution was proof that the human race was "constantly progressing."67 Even if constitutions and bills of right are indeed the result of struggles for hegemony, and even as their meaning cannot be separated from the meaning they have for particular readers and interpreters, the French Revolution and with it the idea of a people giving itself a constitution was evidence of a historical break that could be articulated in two types of critical attitude to law and in two politics of law. ${ }^{68}$

One unfolds within the act of judgment located in the institutional process of applying the law in one way rather than another. Kant has this moment in mind when, in the midst of the Revolution, he endorses the mindset of the moral politician, the actor conscious that the right judgment cannot be reduced to the use of instrumental reason and who, in judging, aims to act as a "genuine republican" encompassing the perspective of the whole. ${ }^{69}$ As is well-known, Kant's political theory is complemented by his analysis of the faculty of imagination operative in aesthetic judgment. ${ }^{70}$ The aesthetic judgment, which is neither rationally subsumed under a rule nor a fully subjective expression of emotion, captures also the plight of the moral politician as law-applier. Although the way the moral politician approaches a particular situation is undetermined by any rule (a matter of "reflective" instead of "determinative" judgment in Kant's aesthetic vocabulary), it still claims general assent. No wonder that aesthetics, "coherence," has become the focus of modern liberal-constitutional theories of judging. ${ }^{71}$ In both, one is called upon to visualize oneself in everyone else's place. To say "this painting is beautiful" is not only about what one feels about it. This statement seeks more general validity, just as the claim of adopting a constitution sought validity beyond the immediate concerns of the Revolution, and just as the legal judgment claiming "this is valid law" is different from the statements "this is good" or "this is useful." This is also how that claim was understood by Kant

67 See, in particular, KANT, supra note 51, at 182-85.

68 Kant viewed the human species as consisting of adolescents and, until the Revolution, had few positive things to say about it.

69 See Kant, Perpetual Peace, supra note 3, at 116-25 (especially at 122).

70 KANT, supra note 5. For the suggestion that the Third Critique forms the core of Kant's political theory, see especially HANNAH ARENDT, LECTURES ON KANT'S POLITICAL Philosophy (Ronald Beiner ed., 1982). But see Francoise Proust, KANT ET LE TON DE L'HISTOIRE (1991); ALAIN RENAUT, KANT AUJOURD'HUI 405-15 (1997).

71 The paradigm here is Ronald Dworkin's legal theory. For a brief overview of liberal theories of judging, see KENNEDY, supra note 26, at 97-130. 
and other observers, and what set the paradigm of (Kantian) constitutionalism: the search for validity beyond the inclinations of the speaker.

Liberal jurisprudence has tried to articulate rules for the use of that imagination and for the de-centering of the self in a series of hermeneutical techniques, but Kant suggests something different: to expand toward universality, one must penetrate deeper into subjectivity, law as a crystallization of personal virtue rather than in opposition to it. The world federation should, after all, be ruled by moral politicians! This suggestion cannot be detached from the results of the critical project that, by the onset of the Revolution, had completely destabilized the hubris of having full knowledge of the natural world or of the related naturalist idea of politics as a technology for governing human beings. If the principles of the Rechtslehre remained principles of (rational) natural law, it was at such a high level of abstraction that they could not free lawyers (as "moral politicians") from having to think for themselves. The Pietist search for self-improvement, Bildung, and spiritual perfection prepares a constitutionalist mindset from which to judge the world in a manner that aims for universality, impartiality, and all the virtues of the "inner morality of law": honesty, fairness, concern for others, the prohibition of deceit, injury, and coercion. ${ }^{72}$ Though this is a vocabulary of moral regeneration, it is also the vocabulary of constitutionalism.

Liberal hermeneutics provides one approach to the contemplative, somewhat outer-worldly search for the independence and impartiality needed to carry out the work of judgment so as to use power in a responsible way. The "moral politician" participates in a modern priesthood that accepts Weber's "calling," somewhat resembling the heroes that Weber and the classical realists had in mind when illustrating the virtues of statesmanship. Those virtues were irreducible to instrumental calculations or to the applications of principle. Giving up the dogmatic illusion of total control, they framed the responsible political choice as a judgment in contingency, perhaps somewhat akin to the way Florentine political theory once proposed that "the problem of fortune is a problem of virtue." ${ }^{.73}$ If the critical project has one political consequence, it is pointing to the limits of the power of cognitive

72 For an alternative formulation of this "inner morality," see LON FULLER, THE Morality OF LAW (rev. ed. 1964); see, e.g., J.B. Schneewind, Autonomy, Obligation and Virtue: An Overview of Kant's Moral Philosophy, in THE CAMBridge COMPANION TO KANT 309, 320-21 (Paul Guyer ed., 1992); ONORA O'NEILL, BoundS OF JUSTICE 65-79 passim (2000).

73 John Greville Agard Pocock, The Machiavellian Moment: Florentine Political Thought and the Atlantic Republican Tradition 157 (1975); see generally id. at 156-82. This is also suggested in R.B.J. WALKER, INSIDE/OUTSIDE: 
vocabularies and to the irreducibility of a (free) decision to any (natural or rational) structure.

But constitutional vocabularies do not merely frame the internal world of "moral politicians" conscious of the contingency of their choices. They inform political struggles. Instrumental vocabularies are mastered by technical and administrative bodies and articulate concerns they tend to consider important. By contrast, such constitutional vocabularies as "self-determination," "fundamental rights," "division and accountability of power," and so forth, with all their historical thickness, contest the structural biases of present institutions and politicize what otherwise appears as routine administration. The Revolution was not just another development on the stage of European politics. It questioned the stage itself. This was the very point of its constitutional rhetoric: to destabilize dynastic administration (as technology). Hence Kant's extraordinary optimism. ${ }^{74}$ From then on, even as there may be temporary reversals, what had taken place "can never be forgotten since it has revealed in human nature an aptitude and power of improvement of a kind which no politician could have thought up by examining the course of events in the past."75 In 1798, Kant celebrated the spontaneous and disinterested enthusiasm of the observers of the French Revolution. He opposed Prussia's counter-revolutionary attacks against France as attacks against freedom. Though moral regeneration was certainly on Kant's agenda, it did not exhaust his political program. Mere instruction at schools on order to make young people good citizens was "a plan which is scarcely likely to have the desired success." ${ }^{.76}$ Instead, Kant endorsed a republican citizenship that highlighted active political participation to reform the state too, with a view of "continuous progress" toward the desired goal of a "universal association of states" in which freedom might become a reality. ${ }^{77}$

What is important here is not so much the realism of Kant's prognosis of "perpetual peace" or choosing between the many forms of international order

InTERNATIONAL RELATIONS AS POLITICAL THEORY 36, 38-47 (1993). To associate Kant with Machiavelli seems initially odd. The ideal of the "moral politician" seems the antithesis of the separation between private and public morality underlying Machiavellian virtù. Nevertheless, both stress the way the individual judgment (in contrast to the character on which it is based) remains irreducible to rule-following.

74 The contrast between Kant's 1784 Essay and his later writings during the revolution is highlighted in Alexis Philonenko, De la démocratie chez Kant et Fichte, 2 PHILOSOPHIE POLITIQUE 53, 56-57 (1992).

75 KANT, supra note 51, at 184.

76 Id. at 189 .

77 See, e.g., KANT, supra note 2, at 119 (§ 61). See also Tosel, supra note 62, at 94-99. 
he projected, or even the strength of the public realm as a forum for political contestation. Rather, what is important is the use of the constitutional vocabulary to express a fundamental critique of present politics. The ancien régime existed for the privilege of particular estates; the Revolution, as Sieyès put it, upheld the rights of the "universal estate." ${ }^{178}$ For Kant as for other sympathizers, the historical meaning of the French Revolution was the entry into politics of the regulative idea of universality. As the revolutionaries claimed, and as observers indeed understood, the Revolution was not one more episode in the traditional ebb and flow of dynastic struggles. A qualitatively novel form of political order was being created that set as its horizon the liberation of humanity itself. ${ }^{79}$ This effect, this aesthetic effect, was brought about by the language of constitutionalism. The extreme inequality of a society of estates was articulated and attacked by the vocabulary of the rule of law.

The virtue of constitutionalism in the international world follows from a similar universalizing focus, allowing extreme inequality in the world to be not only shown but also condemned. This inequality may be explained by historical causes and described in economic or sociological terms. But something like a constitutional vocabulary is needed to articulate it as a scandal insofar as it violates the equal dignity and autonomy of human beings. It can be used to show that the suffering created by an international intellectual property regime, for example, or an imperial war in the Middle East, is more than private suffering, that these choices violate more than the interests or benefits of their immediate victims, and that the scandals emerging from them are not calculable as "costs" to be offset by future "benefits." The use of the constitutional vocabulary, like Kant's aesthetic judgment, transforms individual suffering into an objective wrong that concerns not just the victim, but everyone. If calculation is needed, then "all" must be counted as the cost.

Dying of malaria when the available technical and economic resources are sufficient to prevent this, or suffering torture in a hidden detention camp, are not just unfortunate historical events touching only the physical persons concerned. In a secular society, it is the political business of constitutionalism to endow such events with sacredness or with a symbolic meaning

78 Emmanuel Joseph Sieyes, Qu’est-Ce Que Le TIERs-ÉtAT? (Arno Press 1979) (1789).

79 For the extent to which Kant saw the Revolution as an exception to normal politics (that justifed relaxing even many of his otherwise absolute principles), see Jacques d'Hondt, Kant et la Révolution francaise, 2 Philosophie PolitiQue 39, 46-51 (1992). 
that lifts them beyond their individuality. They work as "archetypes," 80 or normative moorings for political identity, without which expert systems could not be distinguished from crack parties, and calculations of costs and benefits might as well be carried out by lottery. It may be unfortunate that international relations lack a more robust constitutional tradition, and recent constitutionalist writings are disappointing in their nostalgic attachment to traditional diplomatic institutions. One thing that lawyers may perhaps learn from the constitutional failure in the EU last year is that constitutional politics is resistant, indeed opposed, to managerialism. It cannot survive as an instrumental project. In a fundamentally unfree and unequal world, constitutionalism, as Kant might have put it, carries the ideal of a free and self-determining humanity.

80 The suggestion of the significance of the "absolute" prohibition of torture as "archetype" is from Jeremy Waldron, Torture and Positive Law: Jurisprudence for the White House, 105 COLUM. L. REV. 1681 (2005). 